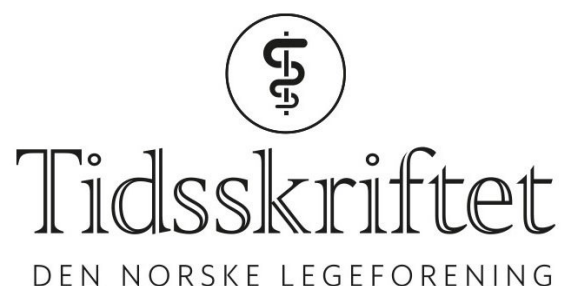

DEN NORSKE LEGEFORENING

\title{
Langtids EKG: Riktig bruk er viktig
}

KOMMENTAR

\section{KNUT GJESDAL}

E-post: knut.gjesdal@medisin.uio.no

Knut Gjesdal er emeritusprofessor fra Institutt for klinisk medisin Universitetet i Oslo.

Forfatteren har ikke oppgitt noen interessekonflikter.

Jarle Jortveit og medarbeidere har nylig presentert en analyse av ett års bruk av langtids EKG-registreringer ved Sørlandet sykehus, Arendal (1). Funnene bekrefter de Helge Grendahl og jeg publiserte i en mindre studie i Tidsskriftet i 1993 (2). Forfatterne konkluderer med at de behandlingsmessige konsekvensene av EKG-undersøkelsen var fa, spesielt hos pasienter uten tidligere kjent hjertesykdom, og argumenterer for økt bruk hos pasienter med høy risiko for atrieflimmer og redusert bruk på indikasjonen palpitasjoner. Det er generell faglig enighet at om at en skal lete etter paroksysmal atrieflimmer hos pasienter som har forhøyet CHA2DS2-VASC-skår som til tilsier antikoagulasjonsbehandling ved flimmer, så det er en viktig påpekning.

Vi mangler europeiske dedikerte retningslinjer, men det finnes amerikanske fra 2017 (3). Mange flimmerpasienter kan ha velkontrollert hvilepuls, men blir slitne fordi pulsen øker urimelig raskt og mye ved anstrengelse. 24-timers EKG ofte berettiget på slik mistanke. Man kan også finne ut om flimmeranfallet starter ved bradykardi (betablokker kontraindisert), ved normal frekvens og supraventrikulære ekstrasystoler (antiarytmika kan være indisert) eller ved takykardi (vurdér betablokker).

Jortveit og medarbeidere er skeptiske til bruk av langtids-EKG ved palpitasjoner fordi det sjelden får behandlingsmessige konsekvenser. Det er i strid med de amerikanske anbefalingene, som gir uforklarte palpitasjoner en klasse I indikasjon (evidensstyrke BRandomiserte studier). Min erfaring er at palpitasjoner ofte gir betydelig engstelse, og det å undersøke ordentlig og finne årsaken, er en forutsetning for å kunne berolige pasienten. Og en gang imellom gjør man overraskende funn som må følges opp. Besvimelser som ikke har klart vasovagalt preg eller annen åpenbar forklaring, henvises etter min erfaring for sjelden, ettersom kardialt utløste synkoper er potensielt alvorlige (4).

De største svakhetene ved dagens praksis er etter min mening ikke overforbruk, men at mange som burde få undersøkelsen, ikke gjør det, at henvisningene er for dårlige og at tolkningen blir dårligere fordi pasientene ikke leverer logg over aktivitet og symptomer i registreringsperioden. Langtids-EKG er en billig, lite besværlig, komplikasjonsfri undersøkelse som fortsatt bør være lett tilgjengelig. 
1. Jortveit J, Lislevand TH, Rysstad L et al. Funn og konsekvenser ved langtidsregistrering av EKG. Tidsskr Nor Legeforen 2020;140. doi:10.4045/tidsskr.19.0434. [PubMed][CrossRef]

2. Grendahl H, Gjesdal K. Den praktiske nytten av ambulant langtids EKG-registrering. Tidsskr Nor Lægeforen 1993; 113: 839-41. [PubMed]

3. Steinberg JS, Varma N, Cygankiewicz I et al. 2017 ISHNE-HRS expert consensus statement on ambulatory ECG and external cardiac monitoring/telemetry. Heart Rhythm 2017; 14: e55-96. [PubMed][CrossRef]

4. Brignole M, Moya A, de Lange FJ et al. 2018 ESC Guidelines for the diagnosis and management of syncope. Eur Heart J 2018; 39:1883-948. [PubMed][CrossRef]

Publisert: 30. mars 2020. Tidsskr Nor Legeforen. DOI: 10.4045/tidsskr.20.0200

(C) Tidsskrift for Den norske legeforening 2020. Lastet ned fra tidsskriftet.no 